\title{
STMN1 wt Allele
}

National Cancer Institute

\section{Source}

National Cancer Institute. STMN1 wt Allele. NCI Thesaurus. Code C129043.

Human ST MN 1 wild-type allele is located in the vicinity of 1 p36.11 and is approximately $23 \mathrm{~kb}$ in length. This allele, which encodes stathmin protein, is involved in the disassembly of microtubules. 